\title{
Homosexuality in Ghana: Morality, Law, Human Rights
}

\author{
Raymond A. Atuguba ${ }^{1,2}$ \\ ${ }^{1}$ Harvard Law School, Cambridge, USA \\ ${ }^{2}$ School of Law, University of Ghana, Ghana \\ Correspondence: Raymond A. Atuguba, Visiting Professor of Law and Henry J. Steiner Visiting Professor in \\ Human Rights (2018-2019), Harvard Law School, Cambridge, MA, ratuguba@law.harvard.edu; Associate \\ Professor and Dean, University of Ghana School of Law, ratuguba@ug.edu.gh or atugubaatuguba@yahoo.com
}

Received: June 23, 2019

Accepted: September 12, $2019 \quad$ Online Published: November 28, 2019

doi:10.5539/jpl.v12n4p113

URL: https://doi.org/10.5539/jpl.v12n4p113

\begin{abstract}
This paper addresses the status of Lesbian, Gay, Bisexual, and Transgender (LGBT) persons in Ghana. Firstly, it examines the effects of Ghana's laws and law enforcement practices on the ability of members of the LGBT community to live openly and freely and to enjoy all the rights guaranteed other citizens. Secondly, it explores the current state of affairs within the country as regards the LGBT population, addressing specifically, how members of the community are treated by Ghanaian society. On the whole, the paper advocates for the recognition of members of the LGBT community as equal members of Ghanaian society, deserving of the rights to life, liberty, and the pursuit of happiness.
\end{abstract}

Keywords: Ghana, homosexuality, human rights, law, LGBT

\section{Introduction: The Law on Homosexuality in Ghana}

Homosexual conduct is criminalized by Ghana's criminal laws ${ }^{1}$; or at least, it seems to be. The language of section 104(1)(b) of the Criminal Offences Act, 1960 (Act 29) ${ }^{2}$ which bears sole responsibility for purportedly abhorring consensual same-sex intercourse is, with very little argument, shrouded in uncertainty and patent ambiguation as regards the boundaries of its proscription, vaguely termed, "unnatural carnal knowledge", This is because the provision does not clarify the laid down parameters for sexual relations in an "unnatural manner". In an interview with Human Rights Watch", an Assistant Commissioner of Police in Ghana, admitted this when he said, "the term unnatural carnal knowledge is vague, does not have any clear meaning in law, creates difficulties in consistent interpretation and its application is used to target LGBT people"(Human Rights Watch, 2017).

Nevertheless, by this law, the unnatural carnal knowledge of another person who is 16 years or above, with or without the person's consent is prohibited. ${ }^{5}$ And, notwithstanding the glaring lack of clarity, one thing is plain: consensual same-sex relations between two men is a criminal offence within the meaning of the Criminal Offences Act. This rationalization is surmised from the same enactment, specifically section 99, which conveniently provides that, evidence of carnal or unnatural carnal knowledge is proved by the least degree of penetration. ${ }^{6}$ With this as a guiding rule, although several conjugated forms of penetration can be constructed from the wording of the law, we can boldly extract least degree of penetration to vividly include penal-anal penetration, also known as sodomy.

Judging by historical affiliations, the present criminalization of sodomy in Ghana is inspired by the colonial laws of her former colonial rulers, the British. Most of the countries in the world that still criminalize homosexual

\footnotetext{
1 Ghana's criminal law statute is the Criminal Offences Act, 1960 (Act 29) as amended.

${ }^{2}$ Section 104(1) of the Criminal Offences Act, 1960 (Act 29), states that: A person who has unnatural carnal knowledge: (b) of another person of not less than sixteen years of age with the consent of that other person commits a misdemeanor.

${ }^{3}$ The law in section 104(2) defines unnatural carnal knowledge as sexual intercourse with a person in an unnatural manner, or with an animal.

${ }^{4}$ Human Rights Watch is an independent human right advocacy group that investigates and reports abuses happening in all corners of the word and direct their advocacy towards governments, armed groups and businesses.

5 See: section 104(1)(a) and (b) of the Criminal Offences Act, 1960 (Act 29).

${ }^{6}$ Section 99 of the Criminal Offences Act (Act 29) provides that, where, on the trial of a person for a criminal offence punishable under this Act, it is necessary to prove carnal knowledge or unnatural carnal knowledge, the carnal knowledge or unnatural carnal knowledge is complete on proof of the least degree of penetration.
} 
conduct are former British colonies (Han, E. \& O'Mahoney, J., 2014) and Ghana is one of them. British abhorrence of homosexuality is traceable to the Common Law, well before the enactment of what is probably the first British criminal anti-sodomy law in 1533. ${ }^{7}$ The Act was repealed in 1553 and reinstated in 1558 as a capital offence. However, under the Offences against the Person Act of 1861, the crime of sodomy was punishable by penal servitude of between 10 years and life imprisonment. ${ }^{8}$ These laws were transplanted into British colonies such as Ghana. In contrast, there were no anti-sodomy laws in French colonies in Africa. This is because, even though sodomy was a heinous crime before the French Revolution, the French Penal Code of 1791 promulgated a new penal code abolishing the criminalization of sodomy and made no mention of private same-sex relations. The Napoleonic Code of 1810 confirmed this policy (Jackson, 2009). Thus, those laws did not make their way to French Colonies in Africa (Anderson, B. 2007), with the exception of countries such as Senegal.

Having discovered the law respecting homosexual conduct in Ghana, it is argued that Ghana's criminal statute does not outlaw "homosexuality" or "homosexual expression" in general. Homosexuality could mean the mere sexual attraction to a person of the same gender, and not necessarily unnatural carnal knowledge or sodomy. This implies that a person who identifies as "gay", but does not engage in unnatural carnal knowledge would not be caught by Ghana's criminal laws. Nevertheless, a heterosexual person who engages in "unnatural carnal knowledge" commits an offence, although (s)he is not homosexual. It may, therefore, be reasonably proposed that, a person belonging to the LGBT community is permitted by the confines of Ghanaian law, to live openly as a homosexual - with the opportunity at will to publicly show affection to another person of the same-sex, and engage in all acts attendant to such affection, and which fall short of the requisite degree of penetration.

The absence of gender-neutrality within the relevant provision of the criminal law also comes to judgment. As noted earlier, the Ghanaian Criminal Offences Act insists that "penetration" is an essential element in proving carnal knowledge, whether natural or unnatural. ${ }^{9}$ By this logic, sexual intercourse cannot be established in law where penetration is wanting. It has accordingly been held that no lesser act of sexual gratification such as, "brush work" 10 would suffice to establish carnal knowledge. It follows that acts associated with lesbianism would ordinarily not meet the "penetration" test established under section 99 of Ghana's Criminal Offences Act for the simple reason that lesbians do not possess a natural penis. ${ }^{11}$ By this, the general understanding of the prohibition seems to exclude sexual activities between two or more women (Carpenter, D., 2004); and it is inconsequential that the women engage the use of sex toys (Smith \& Hogan, 2009). Thus, in Ghana, a woman engaged in lesbian activity cannot, technically, be made culpable for offending any law.

On the general front of homosexual lifestyle, in respect of transgenders, the laws of Ghana do not directly address the issue of sex-change or trans-sexualism. It is therefore probable that a biological male who transforms his sex to a female may have sexual intercourse with a male and should, by law, be liable to be apprehended by the authorities, unless the sexual intercourse fell below the requisite level of penetration. This is because the law in Ghana fixes the gender of a person at birth and for all time, and granted the requisite level of penetration, will consider such intercourse as occurring between two biological males.

The laws of Ghana also have no express position on the sexual activities of hermaphrodites. It, however, seems that a hermaphrodite can identify with only one of the sexes, which sex is usually the one he or she is identified with at birth or the sex that has chromosomal, gonadal and genital congruence. On this footing, it is suggested that a hermaphrodite who is identified at birth as male, or who is biologically categorized male, would not violate the criminal laws of Ghana if (s)he engages in sexual activity with a woman, through their vagina.

In the case of bisexuals, only those aspects of their sexual orientation which involve anything other than penal-vaginal penetration, categorised as "unnatural carnal knowledge", are potentially caught by the law. Their other sexual activities are completely legal.

In sum, the criminal law of Ghana, in its bid to forbid same-sex sexual conduct, ended up prohibiting a minute

\footnotetext{
${ }^{7}$ Under the Buggery Act of 1533, whose long title read: "An Act for the punishment of the vice of Buggery (25 Hen. 8 c. 6)", a person convicted of buggery "shall suffer such pains of death and losses and penalties of their good chattels, debts lands tenements, and hereditaments as felons do according to the Common Laws of this Realm".

${ }^{8}$ See: section 76 of The Offences Against the Person Act, 1861.

${ }^{9}$ Section 99 of the Criminal Offences Act, Act 29.

${ }^{10}$ See the judgement of Dotse JSC in Gligah \& Atiso v. The Republic [2010] SCGLR 870 at 879, where the learned Justice of the Supreme Court said: "So long as there was some penetration beyond what is known as brush work, penetration would be deemed to have occurred and carnal knowledge taken to have been completed."

${ }^{11} R v$ Jacobs (1817) Russ \& Ry 331, supports the position that buggery relates only to intercourse per anum by a man with a man or woman, or intercourse per anum or per vaginam by either a man or a woman with an animal.
} 
aspect of homosexual relations-sodomy. Again, by focusing exclusively on unnatural carnal knowledge, the Criminal Offences Act intentionally or unintentionally made illegal, other sexual acts also performed by heterosexuals. The ambit of unnatural carnal knowledge would therefore suggest that it is a criminal offence, punishable by the laws of Ghana, for a male to penetrate the anus (sodomy) or mouth (felatio) ${ }^{12}$ of a female or male with his penis. Consequently, the only mode of sexual intercourse which does not offend Ghanaian law is sex per vaginam, namely, sexual intercourse through the vagina by penile penetration.

Flowing from the above analysis:

1) Felatio, the sexual stimulation of a man's genitals using the tongue and lips, is a criminal act under the laws of Ghana.

2) Sodomy or buggery is a criminal act under the laws of Ghana.

3) Bestiality is a criminal act under the laws of Ghana.

4) Gay sexual intercourse is a criminal act under the laws of Ghana, only if it involves unnatural carnal knowledge.

5) Lesbianism is not criminalised under the laws of Ghana.

6) A transsexual, or a medically transformed male (now female) may yet commit a crime in Ghana if (s)he has unnatural carnal knowledge with a man, and vice versa.

7) A hermaphrodite does not commit a crime in Ghana if his or her sexual activity is par vaginam whether biologically identified as male or female.

8) A bi-sexual does not commit a crime in Ghana if his or her sexual activity does not involve unnatural carnal knowledge.

From the above, it is evident that as per the laws of Ghana, homosexuality is not expressly illegal. The laws are therefore open to interpretation and contestation. Ultimately, it is safe to say that aside the particular proscription of types of sexual activity, homosexuals in Ghana are entitled to all the other rights, sexual or otherwise, that every citizen is entitled to enjoy.

\subsection{The State of Unnatural Carnal Knowledge in other Common Law Countries}

The cognate term "against the order of nature", used in Nigeria ${ }^{13}$, Uganda ${ }^{14}$, Kenya $^{15}$ and India, ${ }^{16}$, is only a little more helpful than "unnatural carnal knowledge". Under the laws of those countries, the term is explained to mean sexual "intercourse against the order of nature". Even though what constitutes "the order of nature" is in itself not specifically outlined and therefore not beyond debate, the generally accepted position is that sexual intercourse is against the order of nature if the approach employed excludes procreation outright ${ }^{17}$. With this explanation, sexual intercourse is also unnatural if a male intentionally has sex with an animal or if a female intentionally allows an animal to have sex with her (bestiality).

As far back as 1961, case law depicts instances of prosecutions for offences against the order of nature before the Nigerian courts. This is evidenced by the High Court decision of Thomas E. Dowling v Inspector General of Police $^{18}$, before Chief Justice De Lestang. The curt facts are these: the appellant was a happily married man who had committed an unnatural offence with a male person and was later blackmailed by his accomplice. He went to the police for protection and made a full and free confession. Both the appellant and the blackmailer were charged separately before two different courts. The appellant was convicted of an unnatural offence with a male person contrary to section 214 of the Criminal Code and sentenced to imprisonment for six months. On an appeal

\footnotetext{
${ }^{12}$ In the Indian case of Khanu v. Emperor, AIR 1925 Sind 286, the court held that coitus per mouth is penetration within the intendment of section 377 of the Indian Penal Code and hence is unnatural carnal knowledge.

${ }^{13}$ Section 214 of the Criminal Code Act, 1990, of Nigeria states: "Any person who - (1) has carnal knowledge of any person against the order of nature; or (2) has carnal knowledge of an animal; or (3) permits a male person to have carnal knowledge of him or her against the order of nature; is guilty of a felony, and is liable to imprisonment for fourteen years."

${ }^{14}$ See section 145 of the Penal Code Act of Uganda, (Chapter 120) 1950.

${ }^{15}$ Section 162 of the Penal Code of Kenya (Chapter 63) (Revised 2009).

${ }^{16}$ Section 377 of the Indian Penal Code (1860) states that: "Unnatural offences. --Whoever voluntarily has carnal intercourse against the order of nature with any man, woman or animal, shall be punished with imprisonment for life, or with imprisonment of either description for a term which may extend to ten year, and shall also be liable to fine."

${ }^{17}$ In Lawrence v. Texas 519 US 558 (2003), it was stated “... early American sodomy laws were ... to prohibit non- procreative sexual activity more generally...”

18 Thomas E. Dowling v Inspector General of Police (1961) All N.L.R. 811.
} 
against the sentencing, appellant argued, inter alia, that such offences were no longer considered serious crimes in many parts of Europe. The court found this to be untenable and reiterated Nigeria's firm resolve to maintain such laws in its statutory books. De Lestang C.J delivered himself, thus:

"Whatever may be the view taken of such offences elsewhere, it is clear that in Nigeria it is still considered grave since the Law prescribes a maximum punishment of fourteen years imprisonment for it".

This is still the law in Nigeria.

In Kenya, there has been unbridled activism for LGBT rights through judicial interventions. However, and somewhat expectedly, all these efforts have been shot down by the arbiters of the court. In the 2019 ruling of Petition $150 \& 234$ of 2016 (consolidated), ${ }^{19}$ the court found that sections 162, 163 and 165 of the Penal Code which criminalize private consensual sexual conduct between adult persons of the same sex, did not violate the rights of LGBT Kenyans to non-discrimination, health, a fair trial, security of the person, freedom of conscience, religion or belief, human dignity or privacy. Presiding judge Roselyne Aburili said: "The petitions had no merit" and further propounded that decriminalizing same-sex relations contradicts constitutional values and the customs of the Kenyan people (Mpungu, P., 2019).

While the afore-mentioned African countries have maintained the effect of "offence against the order of nature" in their statute books, in September 2018, the Indian Supreme Court unanimously held that the infamous section 377 of the Indian Penal Code was to be struck down to the extent that it criminalized "gay" sex between two consenting adults. ${ }^{20}$ The ruling overturned a 2013 judgement that upheld the colonial-era law, under which gay sex is categorised as an "unnatural offence". The court has held that discrimination based on sexual orientation is a fundamental violation of rights (BBC, 2019). Like Ghana, Nigeria, and Kenya, India was colonised by the British, and inherited their anti-gay laws.

\section{The International Revolution}

Indubitably, in Europe and the United States of America, the rights of LGBT people are duly acknowledged and the concept of homosexuality is largely embraced-manifested by their laws which recognize same-sex marriages. In the summer of 2015, the US Supreme Court voted in favour of legalising gay marriage across all fifty US states in the landmark decision of Obergefell $v$ Hodges $^{21}$. The ruling has been described as the most "historic" development in US civil rights relations in generations; once again bringing gay rights and marriage into the fore globally and specifically in Africa. What has become apparent is that Africa and the US are not experiencing the same challenges; the debate is different. The US' gay rights debate has been in the making for decades and has now progressed to the stage where gay marriage has been legalised across the country (BBC News, 2015). This does not mean that gays and members of the LGBT community are completely free from the harsh realities of homophobia and persecution often perpetrated against them by family, churches, and members of the general public (Bernadette Barton, 2012).

As disturbing as this may sound, homosexuality was deemed as a psychological disorder in the 1950s in the United States; the American Psychiatric Association's diagnostic manual enlisting homosexuality as a Sociopathic Personality Disorder in 1952. The following year, President Dwight D. Eisenhower signed an Executive Order that banned homosexuals from working for the federal government. Eventually, in 1961, Illinois became the first state to decriminalize homosexuality by repealing their sodomy laws (CNN Library, 2019).

In the United Kingdom, same-sex couples became legally free to marry under UK law in 2014. Today, LGBT citizens have many of the same legal rights as non-LGBT citizens and the UK provides one of the highest degrees of liberty in the world for its LGBT communities. In ILGA-Europe's ${ }^{22} 2015$ review of LGBT rights, the UK received the highest score in Europe, with $86 \%$ progress toward "respect of human rights and full equality" for LGBT people and 92\% in Scotland alone (ILGA-Europe, 2015). Additionally, in 2016, some 35 openly gay and lesbian Members of Parliament were serving in the House of Commons; more than any other country in the

\footnotetext{
${ }^{19}$ EG \& 7 others v Attorney General; DKM \& 9 others (Interested Parties); Katiba Institute \& another (Amicus Curiae).

${ }^{20}$ Navtej Singh Johar \& Ors. v. Union of India the Secretary Ministry of Law and Justice. Writ Petition (Criminal) No. 76 of 2016, India: Supreme Court, 6 September 2018. Unnatural sex with minors and bestiality still remains a crime in section 377 of the IPC.

${ }^{21} 135$ S. Ct. 2584 (2015).

${ }^{22}$ ILGA-Europe is the European region of the International Lesbian, Gay, Bisexual, Trans and Intersex Association. It is an advocacy group promoting the interests of lesbian, gay, bisexual, transgender and intersex persons, at the European level.
} 
world ${ }^{23}$ (Tonkin, 2016).

Indeed, advocacy for LGBT rights in the West and its acceptance pervades even in political circles. For instance, in the United Kingdom, Kezia Dugdale, the former Labour party leader, revealed in April 2006 that she had been in a relationship with a woman and in so doing became the fifth key political figure and fourth party leader in Scottish politics to come out as gay (McVeigh, T., 2016). Later, in June of 2017, Leo Varadkar was elected Ireland's first openly gay Prime Minister (McDonald, H., 2017). In the same month, Ana Brnabić was elected both as Serbia's first female, and first openly gay Prime Minister (MacDowall, A., 2017).

At present, Africa as a whole cannot boast of a general alignment towards a gay-friendly society, let alone public acceptance of openly gay political leaders. However, it can be assertively stated that LGBT status is legal in 21 of the 54 African Countries (Wikipedia, 2014). Furthermore, South Africa can be heralded as the pioneering artist, championing the cause of LGBT rights on the African platform by decriminalizing the prohibition of consensual same-sex, marked by the 1998 decision of the Constitutional Court of South Africa in National Coalition for Gay and Lesbian Equality and Another v Minister of Justice and Others, ${ }^{24}$ which struck down the laws prohibiting consensual activities between men. In 2005, the Constitutional Court in Minister of Home Affairs and Another v Fourie and Another; Lesbian and Gay Equality Project and Others v Minister of Home Affairs and Others ${ }^{25}$, moved a notch further by holding unanimously that same-sex couples have a constitutional right to marry. South Africa is renowned for its liberal policies regarding the acceptance of people of LGBT orientation. Also, the Afrobarometer network, which conducts public opinion surveys in Africa found Cape Verde to be the most welcoming of homosexual behavior (Dulani, B. et al, 2016).

Moreover, Botswana's High Court ruled, quite recently, in favour of decriminalising homosexuality (BBC News Africa, 2019). In an awe-inspiring unanimous decision, one of the three deciding judges, Judge Elburu tagged laws that prohibited gay sex as "discriminatory" and also firmly pronounced that:

"Sexual orientation is not a fashion statement. It is an important attribute of one's personality."

\section{Human Rights Violations and Discriminatory Laws against people of LGBT status in Ghana}

With much resilience and a firm grip to "morality" and "culture", Ghana appears to be unperturbed by the global move to decriminalize consensual adult same-sex relations and the whirlwind of the integration of same-sex marriages. Recently, the Director of Communications in the Office of the President, in response to rumours that same-sex marriage had been approved by Ghana's President, stated categorically in his public communique: "It will NOT be under his Presidency that same-sex marriage will be legalised in Ghana" (Arhin, E., 2018). The current Speaker of Ghana's Parliament has also emphatically declared that homosexuality has no place in the Ghanaian society and cautioned that he would rather resign than preside over any debate on the floor of Parliament concerning same-sex matters (GhanaWeb, 2018). These statements are consistent with those made by previous political leaders in Ghana.

It is on this premise that state-sponsored homophobia ${ }^{26}$ thrives in Ghana and violence against homosexuals is ubiquitously engrained in Ghanaian society (Lingiardi et al., 2005). The effects of these statements in weaponizing homophobia are legion. According to the UK Operational Guidance Note, in July 2011, the Minister of Ghana's Western Region ordered law enforcement to arrest "all gay men and lesbians in the west of the country, and called on landlords and tenants to report anyone they suspected of being gay or lesbian." (United Kingdom Home Office, 2013). The 2012 UK Country of Origin Report on Ghana suggested that "persecution often occurs at the hands of, or with the collusion of, the police or other agents of the state". According to the United States Department of State June 2014 Country Report (US Department of State, 2015), sexual minorities faced "widespread discrimination in employment and education, as well as police harassment and extortion attempts", and are often subjected to physical and sexual assaults (UK Border Agency, 2012). Similarly, in 2013, Amnesty International and the British

\footnotetext{
${ }^{23}$ Northern Ireland, which also forms part of the UK, had not joined England, Scotland and Wales in legalising gay marriage. In January 2016, the New First Minister of Northern Ireland, Arlene Foster commented that legalising gay marriage was not "at the top of her in-tray." Her party, the Democratic Unionist Party (DUP) was founded on deeply traditional Christian values and therefore, they are not seeking to "move away from their traditional view of marriage." Despite this view, the DUP maintain their commitment to upholding human rights for all, including those of the LGBT community. See: Tonkin, S. "Two more MPs come out as gay to take House of Commons total to 35 - more than any other parliament in the world" (Daily Mail, 2016) (Accessed 30 October 2016).

${ }^{24}$ [1998] ZACC15.

${ }^{25}$ [2005] ZACC 19.

${ }^{26}$ The term covers a range of negative attitudes toward homosexuality and those who are or are perceived to be homosexual.
} 
NGO Freedom House reported that violence against the LGBT community was prevalent in Ghana and "the persecution of sexual minorities has escalated" (Amnesty International, 2013). The following stories reflect this statement of fact: In mid-September 2009, a lesbian was almost lynched at the hands of an angry mob in the presence of a District Chief Executive (Mayor) and a police man, with impunity (Human Rights Watch, 2017). Similarly, in August 2012 police arrested three young Ghanaian men for "group fun time" and the men spent two weeks in remand prison (Erasing 76 Crimes, 2012).

Embedded in Ghana's legal framework are laws and policies that promote discrimination against LGBT people. As already noted, Ghana's Criminal Offences Act, in its Section 104 criminalises "unnatural carnal knowledge", a term that is generally understood to cover sexual behaviour other than the penetration of a naturally born male's penis into a naturally born female's vagina. In practice, the only persons who have been prosecuted or face threats of prosecution under this law are those who engage in bestiality and LGBTs. This is outrightly discriminatory.

The marriage, adoption, and related laws of Ghana, as transplanted from England and the Middle East, are still quite conservative and would not recognise homosexual marriages. As late as the end of 2016, the Parliament of Ghana passed a law banning same sex couples from adopting Ghanaian children. ${ }^{27}$

Statutory marriage or Marriage by Ordinance in Ghana is strictly between a man and a woman, from a cursory reading of the Marriage Act, CAP $127^{28}$. The Act in section 68(2) supports this proposition by specifying that the registrar shall directly or through an interpreter, address the parties thus: "Do I understand you A.B and C.D that you come here for the purpose of becoming husband and wife?". Again, in the publication of the banns of marriage before a church, section 50(1) of CAP 127 designates the parties to the union as husband and wife. In effect, Ghana's law does not permit a registered Christian marriage between persons of the same sex. This discriminatory treatment is further etched in the First Schedule to CAP 127 where PART A and PART B in reference to the registration of customary marriages, stipulates: Particulars of Husband and Particulars of Wife, respectively. On account of Marriage of Mohammedans, the Forms for the Certificate of Marriage in the Second Schedule is signed by the bridegroom and the bride's wali ${ }^{29}$ and their witnesses, in accordance with sections 24(1) and (2) of CAP 127.

The exclusion of marriage to gay and lesbian people is concomitant with the deprivation of entitlements to the estate of one of the deceased couple upon death intestate. The law regulating intestate succession in Ghana, Intestate Succession Law, 1985 (PNDCL 111) limits beneficiaries of an intestate's estate to spouses, children, parents and customary successors ${ }^{30}$. In the absence of an express devolution of property, a gay or lesbian partner is denied access to the property because in law, they cannot be regarded as spouses.

\subsection{Legal Safeguards for LGBT people in Ghana}

In spite of the overwhelming evidence of discriminatory laws and practices against the LGBT community in Ghana, there are principles of law contained in the Constitution and in statute that, when properly construed, should endeavor to protect persons of LGBT status.

To begin with, the 1992 Constitution of Ghana contains a broad antidiscrimination clause in its Article 17, under which many minority interests have sheltered since the Constitution came into force. Article 17 provides generally for equality for all persons, and prohibits discrimination. The interpretation of the scope of that clause by the Supreme Court in light of the rights of LGBTs, or by state officials who enforce anti-discrimination laws, holds the key to the contraction or expansion of that clause and its implications for marginalised groups such as LGBTs. The Supreme Court of Ghana has made a definite pronouncement on Article 17(2) of the Constitution in T.T Nartey v Godwin Gati, ${ }^{31}$ declaring that lawful discrimination was permissible so long as it did not contravene grounds included in Article 17(2), that is, gender, race, colour, ethnic origin, religion, creed or social or economic status, and provided that it was reasonable and achieved a legitimate basis. Nonetheless, it is submitted that this ruling is not enough to completely address the ingrained discrimination against LGBTs in Ghana, unless a bold and forward-looking interpretation of "social...status" is instituted to include LGBT status.

The principle against non-discrimination is revamped by sections 14 and 87 of the Labour Act, 2003 (Act 651) of Ghana. The combined effect of these rules is that an employer, a trade union or an employer's organization shall

\footnotetext{
${ }^{27}$ Section 86K(a) "Restrictions on intercountry adoption". Children's (Amendment) Act, 2016, (Act 937)

${ }^{28}$ Marriage Act, 1884-1985 CAP 127.

${ }^{29}$ In Islam, Wali is a person responsible for the bride's life before she is married.

${ }^{30}$ See sections 4, 5, 6, 7, 8 of the Intestate Succession Law (PNCDL 111).

${ }^{31}$ [2010] SCGLR 74.
} 
not discriminate against any employee on gender, race, colour, ethnic origin, religion, creed, social or economic status, disability or politics. Again, "social...status" can be reasonably construed to encapsulate LGBT status.

The Constitution also contains an impressive Bill of Rights in its Chapter 5, including Article 33(5), which provides that the list of rights in the chapter is not exhaustive, and incorporates other rights "which are considered to be inherent in a democracy and intended to secure the freedom and dignity of man". LGBT rights may be stolen in under this provision, although the fact that LGBT rights are contested the world over may make it fail to satisfy the "inherent in a democracy" test.

There are, however, other constitutional safeguards applicable to gay and lesbian people enshrined in Chapter 5, namely:

1) Article 12 which guarantees the protection of the fundamental human rights of every person in Ghana, subject to the rights and freedoms of others and the public interest;

2) Article 13 which guarantees the right to life of all persons;

3) Article 14 which acknowledges the right to personal liberty;

4) Article 15 which provides that the dignity of all persons shall be inviolable;

5) Article 19 which is to the effect that any person charged with a criminal offence shall be given a fair hearing within a reasonable time by a court; and

6) Article 21 which highlights the freedom of association.

For the realization of these fundamental human rights principles, the Constitution designates the High Court as the forum for the adjudication and enforcement of human rights claims and a haven for victims of human rights violations, which includes LGBTs. The law in article 33(1) of the 1992 Constitution expressly states that: "Where a person alleges that a provision of this Constitution on the fundamental human rights and freedoms has been, or is being or is likely to be contravened in relation to him, then, without prejudice to any other action that is lawfully available, that person may apply to the High Court for redress" ${ }^{\prime 32}$. The Supreme Court has given impetus to this exclusive jurisdiction of the High Court in human rights matters in the case of Abel Edusei (No.1) v. Attorney General. ${ }^{33}$ Through this judicial machinery, the law gives people of LGBT status whose constitutional human rights have been trammeled, unfettered access to the High Court to pursue a remedy at law. Lamentably, this road-map to safeguarding the rights of LGBTs is seldomly utilized, judging by the fact that there is a paucity of case law that lend judicial credence to the proposition that the High Court is the gate-way to espousing the protection of LGBT rights.

The Constitution in Chapter 6 also incorporates the Directive Principles of State Policy, which are guidelines to aid the executive in policy-making, and to inform the decisions of the judicial and the legislative arms of government. ${ }^{34}$ By these principles the State is mandated to carry out the following:

1) Cultivate among all Ghanaians, respect for fundamental human rights and freedoms and the dignity of the human person (Article 35(4)).

2) Actively promote the integration of the peoples of Ghana and prohibit discrimination and prejudice on grounds of place of origin, circumstances of birth, ethnic origin, gender or religion, creed or other beliefs (which may cover beliefs of LGBTs) (Article 35(5)).

3) Endeavour to secure and protect a social order founded on ideals and principles of freedom, equality, justice, probity and accountability as enshrined in Chapter 5 of the Constitution; and in particular, the State shall direct its policy towards ensuring that every citizen has equality of rights, obligations and opportunities before the law (Article 37(1)).

4) Enact appropriate laws to ensure the protection and promotion of all other basic human rights and freedoms, including the rights of the disabled, the aged and children and other vulnerable groups (LGBTs being one) in the development processes (Article 37(2)(b).

\footnotetext{
${ }^{32}$ Article 140(2) of the Constitution 1992, re-emphasizes the duty of the High Court in enforcing human rights provisions in the constitution, as a court of first instance.

33 See Abel Edusei (No.1) v. Attorney-General [1996-97] S.C.G.L.R 1.

${ }^{34}$ Article 34(1) of the 1992 Constitution of Ghana provides: The Directive Principles of State Policy contained in this Chapter shall guide all citizens, Parliament, the President, the Judiciary, the Council of State, the Cabinet, political parties and other bodies and persons in applying or interpreting this Constitution or any other law and in taking and implementing any policy decisions, for the establishment of a just and free society.
} 
The Commission on Human Rights and Administrative Justice (CHRAJ), established by Article 216 of the 1992 Constitution, is also empowered by its human rights mandate in article 218(a) to investigate complaints of violations of fundamental human rights and freedoms. ${ }^{35}$ According to the 2017 Human Rights Report on LGBTs in Ghana, issued by Human Rights Watch (Human Rights Watch, 2017), CHRAJ has implemented an online complaint system for allegations of discrimination including those which are based on sexual orientation and gender identity. The CHRAJ receives and processes complaints, including those filed anonymously, and collects and publishes the data online. The report stipulates that 36 of the 75 discrimination cases filed with CHRAJ since 2013, were from LGBT people (Human Rights Watch, 2017).

The Constitution also provides for the Police Service of Ghana ${ }^{36}$ and equips the service to perform its traditional role of maintaining law and order. ${ }^{37}$ In line with their duty of service towards the protection of all persons from brutality and physical cruelty, a former Inspector-General of Police, David Asante-Apeatu, vouched for the adoption of more proactive steps and pragmatic approaches to ensure the safety of LGBT people (Ghana Web, 2018).

\section{Ghana's International Obligations towards LGBTs}

It is widely accepted in international human rights law that human rights are universal and inalienable; indivisible; interdependent and interrelated. This universality principle of human rights is captured in the words of Article 1 of the Universal Declaration of Human Rights: ${ }^{38}$ "All human beings are born free and equal in dignity and rights". This document and its definitive principle of the universality of human rights, although soft law ${ }^{39}$, is now considered a part of customary international law ${ }^{40}$. It is the starting point to hold Ghana accountable for violations of the rights of LGBT people as a member of the United Nations.

In the year 2000, on $7^{\text {th }}$ September, Ghana ratified the International Covenant on Civil and Political Rights (ICCPR), further demonstrating her commitment to human rights standards set out in this binding document and publicly announcing her ability to uphold and pursue the course of civil and political human rights (Stand Ghana, 2019). Article 2(1) of the ICCPR enjoins Ghana to respect and to ensure to all individuals within its territory and subject to its jurisdiction, the rights recognized in the Covenant, without distinction of any kind. This principle, therefore, imposes on Ghana a legal obligation to guarantee that all persons present in her jurisdiction enjoy the rights laid down in the ICCPR, regardless of their status. Some of these rights include the right to life and human dignity ${ }^{41}$; equality before the law ${ }^{42}$; and right to personal liberty ${ }^{43}$.

Conversely, LGBTs in Ghana are often not accorded equal rights. The criminalization of private, consensual sex between adults of the same sex, as gallantly displayed in section 104(1)(b) of the Criminal Offences Act of Ghana, offends Article 17 of the ICCPR which prompts State parties to protect individual privacy. The right to privacy of homosexual activity was given judicial pronouncement by the Human Rights Committee in Toonen v Australia $^{44}$. Toonen challenged the laws in the Australian State of Tasmania criminalizing consensual same-sex sexual conduct. The Committee found that it was "undisputed that adult consensual sexual activity in private is covered by the concept of "privacy" under Article 17 of the International Covenant on Civil and Political Rights.

\footnotetext{
${ }^{35}$ The 1992 constitution in article 218 states: "the functions of the Commission shall be defined and prescribed by Act of Parliament and shall include the duty (a) to investigate complaints of violations of fundamental rights and freedoms, injustice, corruption, abuse of power and unfair treatment of any person by a public officer in exercise of his official duties.

${ }^{36}$ Chapter Fifteen of the 1992 Constitution of Ghana.

37 Article 200(3) of the 1992 Constitution of Ghana.

${ }^{38}$ The international human rights movement was strengthened when the United Nations General Assembly adopted of the Universal Declaration of Human Rights (UDHR) on 10 December 1948. Drafted as "a common standard of achievement for all peoples and nations", the Declaration for the first time in human history spell out basic civil, political, economic, social and cultural rights that all human beings should enjoy. (United Nations Human Rights Office of the High Commissioner [OHCHR.org]) (Accessed on $9^{\text {th }}$ August, 2019).

${ }^{39}$ Soft law refers to rules that are neither strictly binding in nature nor completely lacking legal significance. In the context of international law, soft law refers to guidelines, policy declarations or codes of conduct which set standards of conduct.

${ }^{40}$ The concept of customary international law entails two elements, namely State Practice and Opinion Juris. State practice is how states behave in practice that forms the basis of customary law. Evidence of what a state does can be obtained from numerous sources. Examples include, a government's administrative acts, legislation, decisions of courts and activities on the international stage. For example, treaty-making. Opinio Juris is a belief that a state activity is legally obligatory, and this forms the factor which turns the usage into a custom and renders it part of the rules of customary international law.

${ }^{41}$ Article 6 of the ICCPR.

${ }^{42}$ Article 3 and 14 of the ICCPR.

${ }^{43}$ Article 9 of the ICCPR.

${ }^{44}$ Toonen v. Australia, Human Rights Committee Communication No. 488/1992, CCPR/C/50/D/488/1992, 4 April 1994, at para. 8.2.
} 
It did not matter that Mr. Toonen, the author of the communication, had never been prosecuted. The mere existence of the criminal law "continuously and directly interferes with the author's privacy" (United Nations Human Rights, Office of the High Commissioner, 2012).

In the Forum on Minority issues held in Geneva, 2014, the United Nations Special Rapporteur on minority issues, Rita Izsák, announced that minorities continue to face violence or mass atrocities, as numerous situations show globally. Regrettably, Ghana contributes to these numbers even though the prohibition against the subjection of any member of society to torture or to cruel, inhuman or degrading treatment or punishment is expressed in Article 7 of the ICCPR ${ }^{45}$. According to the 2016 US Department of State Country Reports, there were instances where police officers demonstrated reluctance to investigate claims of assault or violence against LGBT persons. Further, gay men in prison were often subjected to sexual and other physical abuse (US Department of State, 2016).

Article 26 of the ICCPR instructs that all persons be made equal before the law without any discrimination. According to this provision, the national laws of the State Parties shall prohibit any discrimination and guarantee to all persons equal and effective protection against discrimination on any ground such as race, colour, sex, language, religion, political or other opinion, national or social origin, property, birth or other status; where sex has been interpreted by the Human Rights Committee to include "sexual orientation" ${ }^{46}$ However, in Ghana, there exist discriminatory laws that prevent same-sex couples from adopting a child. Again, our marriage laws are suited for heterosexuals only. It is submitted that on the authority of cases such as X v Colombia ${ }^{47}$, the differences in treatment of gays and lesbians in Ghana through the denial of the right to adopt children and to be legally wedded, constitute discrimination on grounds of sexual orientation.

Likewise, in 2009, the Committee on Economic, Social and Cultural Rights which is responsible for overseeing the implementation of the International Covenant on Economic, Social and Cultural Rights (ICESCR) affirmed that the non-discrimination guarantee of the ICESCR contained in article 2(2) includes sexual orientation. ${ }^{48}$ The Committee has also explained that the non-discrimination guarantee incorporates gender identity, stating that "persons who are transgender, transsexual or intersex often face serious human rights violations, such as harassment in schools or in the workplace., 49

Ghana signed and ratified the International Covenant on Economic, Social and Cultural Rights (ICESCR) together with its Optional Protocol close to two decades ago (Stand Ghana, 2019), but up till now, socio-economic discrimination against LGBT people strongly pervades in the country. With respect to the right to work $^{50}$ for instance, Sam, a 32-year-old transgender man from Accra, said securing employment is virtually impossible because "no one will hire someone they perceive as woman who presents as a man" According to Teresa, a 28-year-old lesbian, the issue of unemployment because of one's sexual orientation is a major problem because no one wants to give them work (Human Rights Watch, 2017).

The Ghanaian government seems to have forgotten her commitments in Article 6 of the International Covenant on Economic, Social and Cultural Rights which provides that: "The States Parties to the present Covenant recognize the right to work, which includes the right of everyone to the opportunity to gain his living by work which he freely chooses or accepts, and will take appropriate steps to safeguard this right." The Committee on Economic, Social and Cultural Rights has also emphasized that the Covenant "prohibits discrimination in access to and maintenance of employment on grounds of ... sexual orientation.." ${ }^{51}$ Ghana ought to be reminded of these indispensable legal obligations, a breach of which gives rise to state responsibility under international law.

The Convention Against Torture (CAT) is the most comprehensive international treaty dealing with torture ${ }^{52}$.

\footnotetext{
${ }^{45}$ Article 7 of the ICCPR states that: No one shall be subjected to torture or to cruel, inhuman or degrading treatment or punishment. In particular, no one shall be subjected without his free consent to medical or scientific experimentation.

${ }^{46} \mathrm{CCPR} / \mathrm{C} / \mathrm{d} / 499 / 1992$ at para 8.7 .

${ }^{47}$ Colombia, Human Rights Committee Communication No. 1361/2005 (CCPR/ C/89/D/1361/2005), at para. 9. This case was decided by the Human Rights Committee in 2007. The Committee concluded that differences in treatment in the award of pensions to a same-sex partner constitutes discrimination on grounds of sex or sexual orientation.

${ }^{48}$ See Committee on Economic, Social and Cultural Rights, General Comment No 20, para 32.

${ }^{49}$ See Committee on Economic, Social and Cultural Rights, General Comment No 20, para 32.

${ }^{50}$ Article 6 of ICESCR.

${ }^{51}$ Committee on Economic, Social and Cultural Rights, General Comment No. 18 (right to work), at para. 12(b)(1).

${ }^{52}$ Article 1 of the United Nations Convention against Torture and Other Cruel, Inhuman or Degrading Treatment or Punishment is the internationally agreed legal definition of torture: "Torture means any act by which severe pain or suffering, whether physical or mental, is intentionally inflicted on a person for such purposes as obtaining from him or a third person information or a confession, punishing him for an
} 
With no justification whatsoever for its derogation, article 2 of the Convention obliges each State Party to take all necessary measures to prevent acts of torture. The fight against acts of torture has gained so much prominence over the years such that, it has attained the force of a jus cogens norm under international customary law, as was confirmed in the US case of Filartiga $v$ Pena-Irala ${ }^{53}$. The overriding question is: has Ghana fallen short of this standard as regards LGBTs? Lamentably, it has. In Ghana, it can be said that severe pain is meted out to LGBT people based on their sexual orientation with the consent or the acquiescence of public officials, amounting to torture within the meaning of Article 1 of the CAT. In a story recounted by Pearl (an LGBT activist) to Human Rights Watch, she was beaten to a pulp by a police officer and other members of the community of Asankrangwa right before the District Chief Executive (Mayor) because of her sexual orientation (Human Rights Watch, 2017).

The violence and abuse suffered by lesbians and transgender women in Ghana calls for the exposition of the Convention on Elimination of All Forms of Discrimination against Women (CEDAW) concerning sexual orientation. By ratifying the CEDAW, ${ }^{54}$ which enjoins states parties to the Convention to prohibit discrimination which encompasses gender-based violence against women ${ }^{55}$ and to take appropriate measures, including legislative, to ensure the full development and advancement of women in all fields, ${ }^{56}$ Ghana bound herself without limitation to fulfil these obligations. In defiance of these obligations towards women, the societal repercussion is that women in Ghana are more likely than men to experience violence at the hands of their families because of their sexuality, with many of these women forced into marriage or sex work (Bowman, V., 2018).

Ghana is also a signatory to the Convention on the Rights of a Child (CRC), ratified in 1990 (Stand Ghana, 2019). The Committee on the Rights of the Child equally interprets the right to non-discrimination in Article 2(1) of the Convention on the Rights of the Child (CRC) ${ }^{57}$ to include sexual orientation ${ }^{58}$ and gender identity. ${ }^{59}$ In Ghanaian secondary schools, students who are suspected of homosexual conduct are often taken through psychological counselling by the school authorities or are dismissed for allegedly engaging in homosexual activity (Ohene-Otu, R., 2018). These dismissals without any proper probe, impinge the right to education of these pupils spelt out in Article 28 of the $\mathrm{CRC}^{60}$.

Under the African regional system for the protection of human rights, the human rights commitments of Ghana towards gays and lesbians persists. Much like the ICCPR, the African Charter on Human and Peoples' Rights embodies Articles that seek to protect the rights of minority groups, whether directly or indirectly, by imposing on individuals and the State, a duty to respect the rights of all people without discrimination. Article 2 is the basic non-discrimination provision, stating that rights under the Charter must be guaranteed without distinction of any kind such as race, ethnic group, colour, sex, language, religion, political or any other opinion, national and social origin, fortune, birth or other status. Article 3 provides that everyone is equal before the law and is entitled to the equal protection of the law. Articles 4 and 5 of the African Charter entitle every individual to respect of their life and the integrity of their person, and prohibit torture and other cruel, inhuman and degrading treatment or punishment. Article 19 is to the effect that all peoples shall be equal; they shall enjoy the same respect and shall have the same rights; and nothing shall justify the domination of a people by another.

act he or a third person has committed or is suspected of having committed, or intimidating or coercing him or a third person, or for any reason based on discrimination of any kind, when such pain or suffering is inflicted by or at the instigation of or with the consent or acquiescence of a public official or other person acting in an official capacity. It does not include pain or suffering arising only from, inherent in or incidental to lawful sanctions."

${ }^{53} 630$ F.2d 876 (2d Cir. 1980).

${ }^{54}$ This was done in 1986.

${ }^{55}$ General Comment No.19 of the UN Committee on the Elimination of Discrimination Against Women states that the definition of discrimination includes gender-based violence.

${ }^{56}$ See: Article 1, 2 and 3 of the CEDAW.

${ }^{57}$ States Parties shall respect and ensure the rights set forth in the present Convention to each child within their jurisdiction without discrimination of any kind, irrespective of the child's or his or her parent's or legal guardian's race, colour, sex, language, religion, political or other opinion, national, ethnic or social origin, property, disability, birth or other status.

${ }^{58}$ Committee on the Rights of the Child, General Comments No. 4 (Adolescent health and development in the context of the Convention on the Rights of the Child) at para. 6; and No. 3 (HIV/AIDS and the rights of the child), at para. 8.

${ }^{59}$ Committee on the Rights of the Child, General Comment No. 13 (The right of the child to freedom from all forms of violence), at paras. 60 and $72(\mathrm{~g})$ (stressing that States parties must address discrimination against vulnerable or marginalized groups of children including children who are lesbian, gay, transgender or transsexual).

${ }^{60}$ Article 28 of the CRC provides that State Parties recognize the right of the child to education. 
The African Commission ${ }^{61}$ established by the African Charter has explicitly included sexual orientation and gender identity in its soft law instruments - that is, its general comments, resolutions and guidelines, building on its April 2014 resolution $275^{62}$ on the protection against violence and other human rights violations against persons based on their real or imputed sexual orientation or gender identity (Issack, W., 2017). Resolution 275 condemns the increasing incidence of violence and other human rights violations, including murder, rape, assault, arbitrary imprisonment and other forms of persecution of persons on the basis of their imputed or real sexual orientation or gender identity. ${ }^{63}$ The resolution then specifically condemns the situation of systematic attacks by State and non-state actors against persons on the basis of their imputed or real sexual orientation or gender identity ${ }^{64}$ calling on State Parties to ensure that human rights defenders work in an enabling environment that is free of stigma, reprisals or criminal prosecution as a result of their human rights protection activities, including for the rights of sexual minorities. ${ }^{65}$ Finally, it strongly urges States to end all acts of violence and abuse, whether committed by State or non-state actors, including by enacting and effectively applying appropriate laws prohibiting and punishing all forms of violence, including those targeting persons on the basis of their imputed or real sexual orientation or gender identities, ensuring proper investigation and diligent prosecution of perpetrators, and establishing judicial procedures responsive to the needs of victims. ${ }^{66}$

With Ghana being a vibrant member of the international community, it demands of the country to bring the enforcement of its laws up to the threshold of international standards and best practices. The wealth of evidence in the stories cited above, detailing gross human rights abuses based on sexual orientation is in itself proof of Ghana's ailing human rights standards in this regard.

\section{Conclusion}

Civil Society Organizations have indeed become more vocal in advancing the rights of LGBT people in Ghana. At the same time, and with due reference to Isaac Newton's third law of motion, there has been an equal force of opposition vehemently pushing for even stricter sanctions on homosexual conduct in Ghana. In February 2017, a representative of the National Coalition of Proper Sexual Rights and Family Values ${ }^{67}$ and a senior law lecturer at the Ghana School of Law in Accra, called for "proper psychological treatment" for homosexuals in Ghana, adding that the coalition "will propose comprehensive legislation which is solution based to resolve this issue of gay and lesbians' rights." (Osei, L., 2017). In a March 2017 radio interview, a cultural anthropologist and senior member of the Afrikania Mission, a neo-traditional religious movement in Ghana, reportedly called on gay people to "go and hang themselves" if they did not want to change from their ways, (GhanaWeb, 2017).

The current President of Ghana has diplomatically ducked in approving or rejecting the possibility of legal reform of Ghana's laws that criminalize homosexual conduct $^{68}$ (Africa News, 2017). In 2010, the Constitution Review Commission $^{69}$ did same when the Commission declined to include in its draft amendment bill, a direct recognition to gay and lesbian rights in the Constitution.

Homosexuals in Ghana do have rights, as evinced by references to the Constitution, other laws, and the international obligations of that country. However, these rights are not being recognized. Until this is done, and

\footnotetext{
${ }^{61}$ Article 30 of the African Charter provides: An African Commission on Human and Peoples' Rights, hereinafter called "the Commission", shall be established within the Organization of African Unity to promote human and peoples' rights and ensure their protection in Africa.

${ }^{62}$ African Commission on Human and Peoples' Rights Resolution 275: Protection against Violence and other Human Rights Violations against Persons on the basis of their real or imputed Sexual Orientation or Gender Identity. The African Commission on Human and Peoples' Rights (the African Commission), meeting at its $55^{\text {th }}$ Ordinary Session held in Luanda, Angola, from 28 April to 12 May 2014.

${ }^{63}$ Resolution 275, clause 1.

${ }^{64}$ Resolution 275 , clause 2.

${ }^{65}$ Resolution 275 , clause 3.

${ }^{66}$ Resolution 275, clause 4.

${ }^{67}$ The National Coalition for Proper Human Sexual Rights and Family Values is an amalgamated organization of Christian, Muslim and Traditional Rulers, Leaders and Institutions which was inaugurated on the 18th of December 2013 with the sole purpose of providing a focused and researched intellectual response to the growing menace of Lesbian, Gay, Bisexual and Transgender (LGBT) Rights activities in the world.

${ }^{68}$ In an interview with Gulf news, the president said, "I don't believe that in Ghana so far a sufficiently strong coalition has emerged which is having that impact of public opinion that will say, change it; let's then have a new paradigm in Ghana." See "Homosexuality not on Ghana's agenda-President Akufo-Addo (Africa News, 2017) (Accessed on $10^{\text {th }}$ August, 2019).

${ }^{69}$ Constitution Review Commission (2011), Report of the Constitution Review Commission: From a Political to a Developmental Constitution". Presented to His Excellency the President of the Republic of Ghana, Professor John Evans Atta Mills on the 20th of December 2011, Accra: Ghana Publishing Corporation.
} 
with the faint hope that bold spirits will rise to the challenge, homosexuals in Ghana have no choice but to deny themselves or bear enervating violations of their human rights until change comes.

\section{Acknowledgement}

I thank Monica Wayoe-Anokye, Laila Biyira Lipede, Agyenim Agyei-Boateng, Ngmensoma Saanchi, Nadia Torsu, Katherine Aglobitse, Kobby Afari Yeboah, and Lorenda Parker for research and editorial assistance in the course of writing this article.

\section{References}

Africa News. (2017). Homosexuality not on Ghana's agenda-President Akufo-Addo. Retrieved August 29, 2019, from https://www.africanews.com/2017/11/26/homosexuality-not-on-ghana-s-agenda-president-akufo-addo

Amnesty International Annual Report 2013: Ghana. Retrieved August 2, 2016, from http://www.amnestyusa.org/research/reports/annual-report-ghana-2013

Anderson, B. (2007). The politics of homosexuality in Africa. Africana: A Journal of Ideas on Africa and the African Diaspora, 1(1).

Annual Review of the Human Rights of Lesbian, Gay, Bisexual, Trans and Intersex People in Europe. (2015). ILGA-Europe. Brussels. Retrieved August 9, 2016, from http://www.ilga-europe.org/sites/default/files/01_full_annual_review_updated.pdf

Arhin, E., (Director of Communications). (2018). Re: President Akufo-Addo has approved gay marriage. Retrieved August 29, 2016, from https://presidency.gov.gh/index.php/briefing-room/press-releases/635-re-president-akufo-addo-has-approve d-gay-marriage- 2

Barton, B. (2012). Pray the Gay Away: The Extraordinary Lives of Bible Belt Gays. New York University Press, New York and London.

BBC News. (2015). US Supreme Court rules gay marriage is legal nationwide. Retrieved October 30, 2016, from http://www.bbc.com/news/world-us-canada-33290341

BBC News. (2018). India court legalizes gay sex in Landmark ruling. Retrieved August 6, 2019, from https://www.bbc.com/news/world-asia-india-45429664

BBC News. (2019). Botswana decriminalises homosexuality in landmark ruling. Retrieved August 8, 2019, from https://www.bbc.com/news/world-africa-48594162

Bowman, V. (Reporter). (2018). "One guy took a cutlass": gay women at greater risk of violence in Ghana. The Guardian. Retrieved August 29, 2019, from https://www.theguardian.com/global-development/2018/jan/10/gay-women-greater-risk-of-violence-ghana

Carpenter, D. (2004). The unknown past of Lawrence v. Texas, 102 Mich. L. Rev. 1464 at p. 1469. https://doi.org/10.2307/4141912

CNN Library. (2019). LGBT rights milestones fast facts. Retrieved August 6, 2019, from https://edition.cnn.com/2015/06/19/us/lgbt-rights-milestones-fast-facts/index.html

Dulani, B. et al. (2016). Good neighbours? Africans express high levels of tolerance for many, but not for all. Dispatch No.74: Afrobaromaeter. Retrieved August 29, 2019, from https://afrobarometer.org/sites/default/files/publications/Dispatches/ab_r6_dispatchno74_tolerance_in_afric a_eng1.pdf

Erasing 76 Crimes. (2012). Tough life for gays in Ghana. Retrieved August 8, 2019, from https://76crimes.com/2012/10/29/tough-life-for-gays-in-ghana/

GhanaWeb. (2017). Kill yourselves if you can't be straight - Homosexuals told. Retrieved August 29, 2019, from https://www.ghanaweb.com/GhanaHomePage/NewsArchive/Kill-yourselves-if-you-can-t-be-straight-Homo sexuals-told-518288

GhanaWeb. (2018). I'd resign than preside over 'gay'debate—Speaker of Parliament. Retrieved August 7, 2019, from

https://www.ghanaweb.com/GhanaHomePage/NewsArchive/I-d-resign-than-preside-over-gay-debate-Speak er-of-Parliament-650955

GhanaWeb. (2018). Police will provide you safe haven- homosexuals told. Retrieved August 8, 2019, from https://www.ghanaweb.com/GhanaHomePage/NewsArchive/Police-will-provide-you-safe-havens-Homosex 
uals-told-616081

Han, E., \& O'Mahoney, J. (2014). British colonialism and the criminalization of homosexuality. Cambridge Review of International Affairs, 27(2), 268-288. https://doi.org/10.1080/09557571.2013.867298

Human Dignity Trust. (2015). Criminalisation of Homosexuality. Retrieved October 31, 2017, from http://www.humandignitytrust.org/uploaded/Map/Country_Reports/Ghana.pdf

Human Rights First.org. (2014). Report: The State of Human Rights for LGBT People in Africa. Retrieved June 22, 2019, from http://www.humanrightsfirst.org/sites/default/files/HRF-HRC-Africa-Report.pdf

Human Rights Watch. (2017). "No choice but to Deny Who I am”, Violence and Discrimination against LGBT People in Ghana. Retrieved from https:/www.hrw.org/report/2018/01/08/no-choice-deny-who-i-am/violence-and-discrimination-against-lgbtpeople-ghana

ILGA-Europe. (2015). Annual review of the human rights of lesbian, gay, bisexual, trans and intersex people in Europe. $\quad$ Brussels, 2015. Retrieved August 9, 2016, from http://www.ilga-europe.org/sites/default/files/01_full_annual_review_updated.pdf

Issack, W. (2017). African Commission tackles sexual orientation, gender identity: Human Rights Watch. $\begin{array}{llll}\text { Retrieved August 29, 2019, from } & \text { 29, }\end{array}$ https:/www.hrw.org/news/2017/06/01/african-commission-tackles-sexual-orientation-gender-identity

Jackson. (2009). Living in Arcadia: Homosexuality, Politics, and Morality in France from the Liberation to AIDS. University of Chicago Press. https://doi.org/10.7208/chicago/9780226389288.001.0001

Lingiardi, V. et al. (2005). The evaluation of homophobia in an Italian sample: an explanatory study. Archives of Sexual Behaviour, 34(1), 81-94. https://doi.org/10.1007/s10508-005-1002-z

MacDowall, A. (2017). Serbia gets its first female - and gay - prime minister. The Guardian. 15 June 2017. $\begin{array}{llll}\text { Retrieved } \quad \text { October } & 30, & 2017, & \text { from }\end{array}$ https:/www.theguardian.com/world/2017/jun/15/serbia-gains-its-first-female-and-gay-prime-minister-ana-b rnabic

McDonald, H. (Reporter). (2017). Ireland's first gay prime minister Leo Varadkar formally elected. The Guardian. $14 \quad$ June 2017. Retrieved October 30, 2017, from https://www.theguardian.com/world/2017/jun/14/leo-varadkar-formally-elected-as-prime-minister-of-irelan d

McVeigh, T. (Reporter). (2016). Kezia Dugdale reveals she is in a relationship with a woman. The Guardian. $\begin{array}{llll}\text { Retrieved } \quad \text { August } & \text { 2019, from }\end{array}$ https:/www.theguardian.com/politics/2016/apr/02/kezia-dugdale-relationship-with-a-woman-scottish-labou r-referendum

Mpungu, P. (Reporter). (2019, May 23). Kenya's high court upholds ban on same-sex relations. Aljazeera. $\begin{array}{llll}\text { Retrieved } \quad \text { August } & 62019, & \text { from }\end{array}$ https://www.aljazeera.com/ajimpact/kenya-law-gay-sex-crime-190524171340308.html

Ohene-Otu, R. (2018). Human rights and homosexuality in Ghana (MPHIL Dissertation, University of Ghana). $\begin{array}{llll}\text { Retrieved } \quad \text { August } & 29, & 2019, & \text { from }\end{array}$ http://ugspace.ug.edu.gh/bitstream/handle/123456789/26162/Human\%20Rights\%20and\%20Homosexuality $\%$ 20in\%20Ghana.pdf? sequence $=1 \&$ isAllowed $=\mathrm{y}$

Osei, L. (Reporter). (2017). Homosexuals are 'sick' people who need psychiatric treatment - Foh-Amoaning. $\begin{array}{lllll}\text { Ultimate } & \text { FM. } & \text { Retrieved } & \text { August } & \text { from }\end{array}$ http:/ultimatefmonline.com/2017/02/24/homosexuals-sick-people-need-psychiatric-treatment-foh-amoanin g/

Smith \& Hogan. (2009). Criminal Law: Cases and Materials (10th ed.). Oxford University Printing Press, United Kingdom.

Stand Ghana, Human Rights Instruments Ghana Ratified. Retrieved August 10, 2019, from https:/www.standghana.org/your-rights/human-rights-instruments-ghana-ratified/

Tonkin. (2016). Two more MPs come out as gay to take House of Commons total to 35 - more than any other parliament in the world. Daily Mail. Retrieved August 29, 2019, from https:/www.dailymail.co.uk/news/article-3456979/Two-MPs-come-gay-House-Commons-total-35-parliam 
ent-world.html

UK Border Agency, Ghana: Country of Origin Information (COI) Report, Gov UK 11, May 2012. Retrieved August 3, 2016, from https://www.gov.uk/government/uploads/system/uploads/attachment_data/file/311919/Ghana_COI_report_ 2012.pdf

United Kingdom Home Office. (2013). Operational guidance note: Ghana. Retrieved August 19, 2019, from https://www.refworld.org/docid/528370ed4.html

United Nations Human Rights Office of the High Commissioner. (2016). Born free and equal: Sexual orientation and gender identity in international human rights law. HR/PUB/12/06. Retrieved August 29, 2019, from https://www.refworld.org/docid/5065a43f2.html

United States Department of State. (2015). 2014 Country Report on Human Rights Practices-Ghana. Retrieved August 29, 2019, from https://www.refworld.org/country,_USDOS,,GHA,,559bd56828,0.html

United States Department of State. (2017). 2016 Country Report on Human Rights Practices-Ghana. Retrieved August 29, 2019, from https://www.refworld.org/country,„USDOS,,GHA,,58ec8a3313,0.html

Wikipedia. (2019). LGBT rights in Africa. Retrieved August 29, 2019, from https://en.wikipedia.org/wiki/LGBT_rights_in_Africa

\section{Copyrights}

Copyright for this article is retained by the author(s), with first publication rights granted to the journal.

This is an open-access article distributed under the terms and conditions of the Creative Commons Attribution license (http://creativecommons.org/licenses/by/4.0/). 